\title{
Oestrogens and pregnancy maintenance in the mare: For or against?
}

\author{
T.A.E. Stout and W.R. Allen* \\ University of Utrecht Department of Equine Sciences, Section of Reproduction, Utrecht, The Netherlands; *TBA Equine Fertility Unit, Newmarket, UK.
}

\begin{abstract}
Summary
It has been proposed that oestrogen secreted in large quantities by the rapidly expanding blastocyst is responsible for maternal recognition of pregnancy in the mare, as it is in the sow. However, while exogenous oestrogen administration readily prolongs luteal lifespan in dioestrous sows, the recorded effects on dioestrous mares have ranged from the predicted luteostasis to a diametrically opposed, hastened luteolysis. One possible explanation for the contrary results is that, as in the domestic ruminant species, oestrogens (of ovarian origin) actually help to establish the luteolytic cascade. If so, high systemic oestrogen concentrations might be expected to compromise rather than to protect early pregnancy, and there is some evidence that this may be the case. On the other hand, conceptus oestrogens almost certainly have important local intra-uterine effects, for example on myometrial activity, vascularity and endometrial gland secretion, all of which are essential to equine conceptus development.
\end{abstract}

Keywords: $\quad$ pregnancy, mare, oestrogen, conceptus, luteolysis

\begin{abstract}
Östrogenapplikation zur Graviditätsstabilisierung: pro oder kontra?
Es wird unterstellt, dass das von der sich schnell entwickelnden Blastozyste in großen Mengen sezernierte Östrogen verantwortlich ist für die maternale Früherkennung des Konzeptus durch die Stute, wie dies bei der Spezies Schwein der Fall ist. Während die exogene Östrogenzufuhr die Gelbkörperwirkung bei der diöstrischen Sau unbestritten verlängert, stehen sich die bisher berichteten Effekte auf die diöstrische Stute diametral gegenüber mit der Bestätigung der vorhergesagten lutealen Stabilisierung bis hin zur beschleunigten Luteolysis. Eine mögliche Erklärung für diese gegensätzlichen Ergebnisse ist, dass - ähnlich den domestizierten Wiederkäuerspezies - Ovaröstrogene aktuell an der Errichtung der luteolytischen Kaskade beteiligt sind. Trifft dies zu, dürfte erwartet werden, dass hohe systemische Östrogenkonzentrationen die frühe Gravidität kompromittieren und nicht etwa schützen, wofür einige Anzeichen tatsächlich sprechen. Anderseits haben mit an Sicherheit grenzender Wahrscheinlichkeit vom Konzeptus gebildete Östrogene bedeutende lokale intrauterine Effekte wie z.B. auf die myometriale Aktivität, die Perfusion, und die endometriale Sekretion, Funktionen, die für die Entwicklung des equinen Konzeptus essentiell sind.
\end{abstract}

Schlüsselwörter: Trächtigkeit, Stute, Östrogen, Konzeptus, Luteolyse

\section{Introduction}

The embryonic signal responsible for prolonging the lifespan of the maternal corpus luteum (CL) and thereby ensuring the continued high progesterone levels necessary for the maintenance of pregnancy (the "maternal recognition of pregnancy factor"; Short, 1969) has been identified in nearly all of the important domestic animal species; one notable exception is the horse. This is frustrating given that, even in young fertile mares, the rate of early pregnancy loss runs at between 5 and $24 \%$ and is highest at or soon after the expected time of pregnancy recognition (see Ball, 1993 for review). Inadequate embryo-maternal dialogue and failure to prevent cyclical luteolysis almost certainly contributes to these losses. In the pig, phylogenetically the closest domestic relative of the horse, the primary embryonic signal for pregnancy recognition is oestrogen secreted in large quantities by the rapidly elongating blastocysts (Bazer and Thatcher, 1977). Since equine blastocysts (Zavy et al., 1979), like their porcine equivalents but unlike those of many other mammalian species (Gadsby et al., 1980), also secrete large quantities of oestrogens from early in gestation, there has been inevitable speculation that oestrogen is the essential signal for maternal recognition of pregnancy (MRP) in the mare. However, while luteal lifespan in cycling sows can be extended by administering oestrogens at the expected time of pregnancy recognition (see Bazer, 1992 for review), studies examining the effect of systemic or intrauterine oestrogen administration on luteal survival in dioestrous mares have yielded equivocal results. Even more suprisingly, it appears that exogenous oestrogen administration can induce a pregnancy-threatening reduction in luteal activity in early pregnant mares (Stout and Allen, 2000). It is, of course, evolutionarily inconceivable that the equine conceptus would release such large quantities of oestrogen unless it positively influenced early pregnancy and, in this respect, conceptus oestrogens have been proposed to stimulate early conceptus migration and changes in uterine tonicity, blood flow and endometrial secretory activity important to the nutrition of the preimplantation conceptus. This review briefly examines the likely contribution of oestrogens to corpus luteum maintenance or lysis and to the development of the preimplantation horse conceptus. 


\section{Maternal recognition of pregancy in the sow and the mare}

Bazer and Thatcher (1977) proposed that, in the pregnant sow, the suppression of cyclical luteolysis is achieved primarily by an oestrogen-induced redirection of endometrial $P \mathrm{PF}_{2 \alpha}$ secretion from a predominantly myometrium-directed "endocrine" to a luminal or "exocrine" pattern of release. This redirection ensures that the luteolysin, rather than entering the uterine vein and systemic circulation, is sequestered in the uterine lumen where it is unable to reach the corpora lutea. This hypothesis has been supported strongly by studies that have demonstrated that exogenous administration of oestrogen to cycling sows during days 11-15 after ovulation does indeed result in prolonged luteal survival and elevated uterine luminal concentrations of $\mathrm{PGF}_{2 \alpha}$ (see Bazer, 1992 for review). By contrast, in the mare the endometrium does not demonstrate such a 'sidedness' to its $\mathrm{PGF}_{2 \alpha}$ secretion (Franklin et al., 1989) and $\mathrm{PGF}_{2 \alpha}$ is not sequestered in the uterine lumen of the mare during the period of pregnancy recognition (Stout, 1998). Instead, MRP in the mare appears to involve an absolute reduction in uterine $\mathrm{PGF}_{2 \alpha}$ production and/or secretion and, therefore, even if oestrogens are involved in MRP in this species the modus operandi must be different to that in the sow.

\section{Administration of exogenous oestrogens to cycling mares}

In 1959, Nishikawa reported that the administration of the synthetic oestrogen, diethyl-stillboestrol, to mares in mid-dioestrus prolonged the lifespan of the $\mathrm{CL}$. However, subsequent studies of the effects of administered oestrogens on luteal lifespan in cycling mares have yielded apparent effects ranging from luteostatic to luteolytic. In retrospect, it appears that these differences stem largely from the wide range of doses and formulations used and the timing and duration of their administration. In short, it appears that when oestrogens are administered in a manner that causes plasma concentrations to be elevated continuously above the physiological range from before day 10 until beyond day 18 after ovulation, i.e. encompassing the postulated MRP period, prolongation of luteal function tends to result. On the other hand, single doses of oestrogen given at later stages either do not affect luteolysis or hasten its onset by inducing $\mathrm{PGF}_{2 \alpha}$ release. A similar pattern for time of oestrogen administration versus effect on luteal function has been recorded in sheep and cattle (e.g. Mann and Lamming, 1995). In these latter species, however, acute ovarian oestrogen release is a physiological stimulator of cyclical luteolysis whereas chronic exposure is an entirely pharmacological phenomenon because early cattle and sheep blastocysts do not secrete oestrogens (Gadsby et al., 1980). Of course, equine blastocysts do secrete oestrogens and continuous delivery of this hormone to the endometrium is the norm during early pregnancy. Nevertheless, large systemic doses of oestrogen may have uterus-independent effects on the $\mathrm{CL}$ which would also be pharmacological in nature given that maternal systemic oestrogen concentrations do not rise appreciably during the first 35 days of pregnancy (Kindahl et al., 1982). Disappointingly, the administration of physiological amounts of oestrogens via the physiological route (i.e. into the uterine lumen) has proven either inconclusively luteostatic (Vanderwall et al., 1994; Stout, 1998) or apparently pro-luteolytic (Goff et al., 1993). Moreover, interpretation of these studies is complicated by the confounding effects of inserting an oestrogen-releasing device via the cervix or endometrial irritation caused by the implant, both of which can hasten or delay luteolysis (Betteridge et al., 1985). In addition, such devices do not migrate extensively within the uterine lumen and do not therefore deliver their hormone to the whole endometrial surface, as a conceptus must if it is to successfully complete pregnancy recognition (McDowell et al., 1985). It is also of interest that even in the pig, in which oestrogens are central to MRP, intrauterine administration of oestrogen in doses that mimic conceptus secretion has been largely unsuccessful in prolonging luteal lifespan (Roberts et al., 1993).

\section{Oestrogens and the luteolytic cascade}

In the domestic ruminants, luteolysis is effected by $\mathrm{PGF}_{2 \alpha}$ released in large spikes generated as a result of a positive feedback loop established, via appropriate receptors, between luteal oxytocin and endometrial PGF $F_{2 \alpha}$ release. Regulation of this process depends on a dynamic interaction between oestrogen, progesterone, oxytocin and their respective endometrial receptors (see McCracken et al., 1984). In this scheme, oestrogens of ovarian origin facilitate cyclical luteolysis by stimulating an increase in oxytocin receptor numbers. In the mare, it is now largely accepted that luteolysis depends on a similar oxytocin-PGF ${ }_{2 \alpha}$ feedback loop (see Stout and Allen, 1999 for review). If so, it seems reasonable to propose that ovarian oestrogens may facilitate or stimulate the onset of luteolysis in cycling mares. Nevertheless, it is also possible that continuous exposure of the endometrium to oestrogen (e.g. from the conceptus) could interfere with luteolysis by overstimulating and thereby preventing the cyclical upregulation of either endometrial oxytocin or oestrogen receptors. Although conclusive proof for either of these mechanisms is lacking, oestrogens do appear to have an inhibitory effect on oxytocin receptors whose numbers and responsiveness (in terms of $\mathrm{PGF}_{2 \alpha}$ release in response to oxytocin challenge) reach a nadir during oestrus when serum oestrogen concentrations are at a peak (Starbuck et al., 1998). Oestrogen receptor numbers are also lower on day 15 of pregnancy than on day 15 of dioestrous (McDowell et al., 1999). On a cautionary note, however, it appears that in cattle circulating oestrogens, be they administered or endogenous, endanger pregnancy by inappropriately facilitating oxyłocin-induced luteolysis (Mann and Lamming, 1995). To date, the effect of oestrogen administration to pregnant mares has received little attention.

\section{Administration of oestrogens to pregnant mares}

Nishikawa (1959) injected mated mares with stilboestrol between 15 and 17 days after ovulation in an attempt to distinguish 
pregnant from non-pregnant animals by the presence or absence of oestrous signs. He reported no detrimental effect on pregnancy. However, Day and Rowlands (1946) reported that 3 of 4 mares to which they administered stilboestrol as a subcutaneous tablet between 26 and 41 days of gestation aborted 1-2 months later. More recently, Gerstenberg (1999) found that daily administration of oestradiol benzoate to mares during days 23-33 of gestation resulted in a rapid fall in circulating progesterone concentrations. In the light of this latter finding, we performed some preliminary studies to examine the effects of exogenous oestrogen administration on luteal function in early pregnant mares (Stout and Allen, 2000). We found that a single injection of a short acting oestrogen (intravenous oestradiol-17b) on day 14 or 22 of pregnancy had no obvious effect on luteal activity. However, a longer acting preparation (intramuscular oestradiol benzoate) followed 6 hours later by oxytocin injection caused a rapid decline in plasma progesterone concentrations which could not be induced by oxytocin injection alone. In all cases, progesterone concentrations stabilised at around 2-3 $\mathrm{ng} / \mathrm{ml}$ and thereafter began to recover so that the pregnancies were maintained, at least until day 30 when they terminated by injection of a $\mathrm{PGF}_{2 \alpha}$ analogue. To our surprise, the injection of oxytocin 6h after "oestradiol-priming" induced a marked PGFM response in only the day 22, and not the day 14 , pregnant mares. This suggests that the effect of the oestradiol benzoate was not mediated primarily via enhancement of the oxytocin-PGF $2 \alpha$ pathway. Nevertheless, these studies provide preliminary evidence that high circulating oestrogen concentrations can endanger early pregnancy in horses.

\section{Other roles of equine conceptus oestrogens}

Despite the doubts over the involvement of conceptus oestrogen in antiluteolytic signalling, it undoubtedly plays other roles vital to the development of the young conceptus. For example, oestrogens are known to stimulate quantitative and qualitative changes in the composition of histotrophe (e.g. increased total protein and uteroferrin concentrations: McDowell et al., 1987), the sole nutritive source for the conceptus before formation of a stable chorioallantoic placenta begins at around day 45 of gestation. In a similar vein, conceptus/fetal oestrogens have been proposed, either directly or via stimulation of endometrial prostaglandin production, to stimulate an increased flow of blood to the gravid uterus in many species (Bazer and First, 1983); this presumably facilitates increased histotrophe production and nutrient and gas exchange. It is likely that the early gestational increase in uterine blood flow in the mare (Bollwein et al., 1999) is similarly a function of conceptus oestrogen (and/ or prostaglandin) secretion.

It is also interesting that, in the 3 large domestic species in which the early conceptus is known to secrete large quantities of oestrogen (the pig, the horse and the dromedary camel), early embryos undergo a high degree of migration; for embryonic spacing in pigs, to ensure the establishment of pregnancy in the larger left horn in camels and for MRP in horses. Conceptus oestrogens have been proposed, by virtue of their ability to stimulate endometrial prostaglandin secretion, as a potential stimulator of the myometrial contractions that drive equine conceptus migration (Stout and Allen, 2001). Finally, conceptus oestrogens have been proposed as the cause of the dramatic increase in uterine tone that begins around day 16 after ovulation in pregnant mares and peaks between days 20 and 25. This tone has been proposed to hold the unattached conceptus firmly against the endometrium and thus allow more ready uptake of histotrophe by the chorion, and successful invasion of the maternal endometrium by the chorionic girdle during formation of the endometrial cups (Allen, 1979).

\section{Conclusions}

The large quantities of oestrogens produced by the preimplantation horse conceptus are almost certainly vital to ensure adequate secretion and uptake of histotrophe during the prolonged period before formation of a stable chorioallantoic placenta. Furthermore, conceptus oestrogen secretion may contribute to MRP by initiating the blastocyst migration necessary for distribution of the embryonic signal. However, whether oestrogen is luteostatic or luteolytic per se in the mare is yet to be determined and resolution of this conundrum may require study of more defined aspects of the luteolytic pathway, such as endometrial oxytocin and oestrogen receptor populations. Finally, the evidence that oestrogen administration can compromise luteal function in pregnant mares emphasises that the precise mode and route by which this hormone is delivered may dramatically affect its ultimate effect.

\section{Literature}

Allen, W.R. (1979): Maternal recognition of pregnancy and immunological implications of trophoblast-endometrium interactions in equids. In: Maternal Recognition of Pregnancy. Ciba Foundation Symposium, No.64. Amsterdam, Excerpta Medica 323-352.

Ball, B.A. (1993): Embryonic death in mares. In: Equine Reproduction. Eds. A.O. McKinnon and J.L. Voss. Lea and Febiger, Pennsylvania, USA. 517-531.

Bazer, F.W. (1992): Mediators of maternal recognition of pregnancy in mammals. Proc. Soc. Exp. Biol. Med. 199, 373-384.

Bazer, F.W. and First, N.L. (1983): Pregnancy and parturition. J. Anim. Sci. 57, Suppl. 2, 425-460.

Bazer, F.W. and Thatcher, W.W. (1977): Theory of maternal recognition of pregnancy in swine based on oestrogen controlled endocrine versus exocrine secretion of prostaglandin $\mathrm{F}_{2 \alpha}$ by the uterine endometrium. Prostaglandins 14, 397-401.

Bollwein H., Woschee I. And Stolla R. (1999): Uterine Durchblutung während der Gravidtät der Stute. Pferdeheilkunde 15, 595-598.

Betteridge, K.J., Renard, A. and Goff, A.K. (1985): Uterine prostaglandin release relative to embryo collection, transfer procedures and maintenance of the corpus luteum. Equine Vet. J., Suppl. 3, 25-33.

Day, F.T. and Rowlands, I.W. (1946): Serum gonadotrophin in Welsh and Shetland ponies. J. Endocr. 5, 1-8.

Franklin, K.J., Gross, T.S., Dubois, D.H. and Sharp, D.C. (1989): In vitro prostaglandin secretion from lumenal and myometrial sides of endometrium from cyclic and pregnant mares at day 14 post partum. Biol of Reprod. 49 Suppl. 1, Abstract 199.

Gadsby, J.E., Heap, R.B. and Burton, R.D. (1980): Oestrogen production by blastocyst and early embryonic tissue of various species. J. Reprod. Fert. 60, 409-417. 
Gerstenberg, C. (1999): Factors controlling epitheliochorial placentation in the mare. PhD Thesis, University of Cambridge.

Goff, A.K., Sirois, J. and Pontbriand, D. (1993): Effect of oestradiol on oxytocin-stimulated prostaglandin $\mathrm{F}_{2 \alpha}$ release in mares. J. Reprod. Fert. 98, 107-112.

Kindhahl, H., Knudsen, O., Madej, A. and Edqvist, L-E. (1982): Progesterone, prostaglandin $\mathrm{F}_{2 \alpha^{\prime}}$ PMSG and oestrone sulphate during early pregnancy in the mare. J. Reprod. Fert. Suppl. 32, 353-359.

McCracken, J.A., Schramm, W. and Okulicz, W.C. (1984): Hormone receptor control of pulsatile secretion of $\mathrm{PGF}_{2 \alpha}$ from the ovine uterus during luteolysis and its abrogation in early pregnancy. Anim. Reprod. Sci. 7, 31-55.

McDowell, K.J., Adams, M.H., Adam, C.Y. and Simpson, K.S. (1999): Changes in equine endometrial oestrogen receptor a and progesterone receptor mRNAs during the oestrous cycle, early pregnancy and after treatment with exogenous steroids. J. Reprod Fert. 117, 135-142.

McDowell, K.J., Sharp, D.C. and Grubaugh, W. (1987): Comparison of progesterone and progesterone and oestrogen on total and specific uterine proteins in pony mares. J. Reprod. Fert. Suppl. 35, 335342.

McDowell, K.J., Sharp, D.C., Peck, L.S. and Cheves, L.L. (1985): Effect of restricted conceptus mobility on maternal recognition of pregnancy in mares. Equine vet. J. Suppl. 3, 23-24.

Mann, G.E. and Lamming, G.E. (1995): Effect of the level of oestradiol on oxytocin-induced prostaglandin $\mathrm{F}_{2 \alpha}$ release in the cow. J. Endocr. $145,175-180$.

Nishikawa, Y. (1959): Studies on reproduction in horses. Eds: Japan Racing Association.

Roberts, R.M., Xie, S. and Trout, W.E. (1993): Embryo-uterine interactions in pigs during week 2 of pregnancy. J. Reprod. Fert. Suppl. 48, $171-186$.

Short, R.V. (1969): Implantation and the maternal recognition of pregnancy. In: Ciba Foundation Symposium on Foetal Autonomy. Eds.
G.E.W. Wolstenholme and Maeve O'Connor. J. and A. Churchill Ltd., London, UK, 2-26.

Starbuck, G.R., Stout, T.A.E., Lamming, G.E., Allen, W.R. and Flint, A.P.F. (1998): The endometrial oxytocin receptor and uterine prostaglandin secretion in the mare during the oestrous cycle and early pregnancy. J. Reprod. Fert. 113, 173-179.

Stout, T.A.E. (1998): Maternal recognition of pregnancy in the mare. PhD Thesis, University of Cambridge.

Stout, T.A.E. and Allen W.R. (1999): The role of oxytocin in luteolysis in the cycling mare. Reprod. Dom. An. 34, 351-354.

Stout, T.A.E. and Allen, W.R. (2000): Oestrogens during early pregnancy in the mare: Kill or cure? Havemeyer Foundation Mono. Series 2, 15-16.

Stout, T.A.E. and Allen, W.R. (2001): Role of prostaglandins in intrauterine migration of the equine conceptus. Reprod. 121, 771-775.

Vanderwall, D.K., Woods, G.L., Weber, J.A. and Lichtenwalner, A.B. (1994): Corpus luteal function in non-pregnant mares following intrauterine administration of prostaglandin $\mathrm{E}_{2}$ or oestradiol- $17 \beta$. Therio. 42:1069-1083.

Zavy, M.T., Mayer, R., Vernon, M.W., Bazer, F.W. and Sharp, D.C. (1979): An investigation of the uterine luminal environment of non-pregnant and pregnant pony mares. J. Reprod. Fert. Suppl. 27, 403-411.

\section{Dr. T.A.E. Stout}

Assistant Professor of Equine Reproduction

University of Utrecht

Department of Equine Sciences

Yalelaan 12

3581 PA Utrecht

The Netherlands

Tel: + + 31302533080

Tel: ++441638662491 